\title{
Autosomal Recessive Disorder
}

National Cancer Institute

\section{Source}

National Cancer Institute. Autosomal Recessive Disorder. NCI Thesaurus. Code C85866.

An inherited disorder manifested only when two copies of a mutated gene are present. 